\title{
O RUÍDO QUE BROTA DOS MUROS DO PORTO: ENSAIO VISUAL SOBRE O DIREITO À HABITAÇÃO
}

\author{
Inês Barbosa ${ }^{1}$
}

A paisagem urbana contemporânea é encarada, frequentemente, como uma justaposição de ruído visual e sonoro: são os semáforos intermitentes, as letras garrafais dos anúncios publicitários, o alarme do carro que dispara de madrugada, os outdoors com as demandas partidárias, os trolleys dos turistas que sobem e descem a calçada (Schafer, 1993). Não por acaso, construímos bolhas artificiais para nos evadirmos desse constante bulício: circulamos em automóveis privados, colocamos headphones nos ouvidos, escondemo-nos por detrás dos óculos escuros ou do écran do telemóvel, fingimos não ver e não ouvir. Porém, a cidade não cessa de emitir e receber mensagens (Léfebvre, 1996) quantas vezes indisciplinadas - contrariando o discurso dominante, impondo novas narrativas, esgrimando outros vocábulos.

O Porto, a segunda maior cidade portuguesa, tem vindo a sofrer transformações intensas e abruptas decorrentes dos processos de gentrificação. O fenómeno é relativamente recente em Portugal e o seu início pode ser associado à crise derivada da Grande Recessão. Em 2011/2012, o Porto debatia-se com o declínio da população no centro histórico, com um elevado número de edifícios devolutos, com altas taxas de desemprego e precariedade e níveis de pobreza e exclusão social dilatados com a crise (Queirós, 2017). É dessa altura, também, a inclusão de alterações legislativas no campo da habitação, impostas pelo Memorando da Troika e baseadas num modelo não intervencionista e neoliberal: Autorização de Residência para Atividade de Investimento (vulgo, Vistos Gold), Regime Legal do Arrendamento Local, Regime Excepcional de Reabilitação Urbana ou Regime Jurídico de Reabilitação Urbana (Antunes, 2019).

Simultaneamente, a cidade do Porto passa a ser "vendida" como uma marca, como destino europeu predileto, recebendo inúmeras distinções. No período pós-Troika, o turismo surge assim como motor fundamental de recuperação económica, como “panaceia para a crise social e urbana" (Mendes, 2017), uma oportunidade de expandir, radicalizar, aprofundar os processos de gentrificação (Janoschka, 2018). Os números são

\footnotetext{
${ }^{1}$ Universidade do Porto, Portugal. Email: inesbarbosa@letras.up.pt

ORCID id: https://orcid.org/0000-0002-7809-8410
} 
claros: de agosto de 2009 a agosto de 2019, o número de passageiros que passaram pelo aeroporto do Porto aumentou 169\% ( $\mathrm{INE}^{2}$ ); as propriedades listadas no AirBnB aumentaram de 10 para 100.000 entre 2010 e 2018 (Fernandes et al, 2018).

Naturalmente, este boom turístico teve consequências. Se, por um lado, o turismo instigou a reabilitação urbana, a criação de postos de trabalho ou a revitalização de comércio e serviços, por outro lado, abriu-se espaço à concorrência desleal entre estabelecimentos comerciais e turísticos; à precarização do emprego ligado ao sector; e, principalmente, a subida do preço da habitação, afetando, não apenas as classes populares e a população envelhecida, mas também a juventude e uma franja significativa das classes médias. Dados recentes da OCDE (2019) apontam para uma classe média sob pressão, principalmente pelo peso que a habitação tem nos orçamentos familiares, sendo Portugal um dos países onde as rendas mais subiram $(33,2 \%)$.

Relatos de bullying imobiliário, despejos em massa ou o encerramento do comércio tradicional e de espaços associativos foram enchendo as páginas de jornais e alimentando conversas agitadas. Se entre 2017/2018 isso deu origem a uma onda de contestação - tendo sido constituídos coletivos e organizadas manifestações e debates públicos - rapidamente, a debilidade da movimentação social deu lugar ao protesto pontual ou movido por gestos individuais. A luta pelo direito à habitação e à cidade transbordou, pois, para stencils pintados ao cair da noite, para murais criados por artistas indignados/as ou para pichagens espontâneas de moradores a quem foi decretada ordem de despejo.

A pandemia que entretanto assolou as cidades de todo o mundo e que veio pôr em causa a sustentabilidade de uma economia dependente do turismo, em nada abrandou essas expressões reivindicativas. Nem tinham porque abrandar: as rendas pouco desceram, o alojamento local dá sinais de estar apenas a fazer uma pausa estratégica, o apoio estatal e municipal tem sido mais que insuficiente para colmatar as dificuldades dos/as residentes e, por isso, a causa da habitação continua a marcar terreno e a pintar de cores diversas as paredes do Porto.

Este ensaio fotográfico é resultado de uma vontade de captar e interpretar essas mensagens. Ancorada na etnografia urbana e na sociologia andante e visual (Ingold, 2008; Pink, 2003), a investigação permanece, de alguma forma, inacabada. Iniciada em abril de 2019, a recolha continua a ser feita, esporadicamente, em idas e vindas da investigadora

\footnotetext{
2 Instituto Nacional de Estatística.
} 
(Barbosa \& Lopes, 2019). São já mais de 150 imagens de muros e pavimentos, contentores de lixo, vidros de armazéns abandonados, postes de eletricidade, fachadas de hotéis, entre outras superfícies que dão voz a quem poucas vezes é ouvido.

$\mathrm{O}$ ato de caminhar surge aqui como um instrumento de pesquisa, um método de descodificação da cidade, mas também como exercício de fruição estética e emotiva dos lugares que ocupamos. Deambulando de modo errante pelas ruelas desconhecidas ou pelos territórios de sempre, a atenção é dirigida para as contra-visualidades, para as manifestações de resistência. Ainda que haja uma aleatoriedade no andar, há uma intencionalidade no olhar que procura captar esta polifonia. Evocando o exercício de flanêur de Baudelaire e de Walter Benjamin ou a deriva situacionista de Debord, este calcorrear a pé sem rumo, é ele próprio uma tentativa de contrariar a tendência de produtividade capitalista que demanda que sejamos eficazes, que não percamos tempo, que cheguemos rápido ao destino (Crary, 2019). É também, de uma certa forma, uma inspiração no "método peripatético" que via no andar uma forma de imersão e exploração do mundo, baseado na experiência empírica, na observação e reflexão.

As vinte e duas imagens selecionadas para este ensaio dão conta da diversidade de agentes, linguagens, estratégias e destinatários. Há murais elaborados com paciência e rigor estético, cartazes colados em lugares de afixação proibida, rabiscos espontâneos escritos com um simples marcador, autocolantes e stencils espalhados aos sete ventos. Há mensagens diretas contra o poder local que acusam de não regular o mercado da habitação, contra os senhorios/as que se aproveitam do seu privilégio, contra os proprietários dos AirBnB que vivem da especulação imobiliária ou contra os/as turistas que contribuem para a descaraterização da cidade e para o aprofundamento das desigualdades. Há palavras iradas, trocadilhos irónicos, humor, subversão ou tentativas de enternecer quem por eles passa. São vozes divergentes na forma mas, em grande medida, convergentes numa crítica relativamente ao rumo que a cidade tem vindo a tomar no plano urbanístico, social e político.

Os registos coletados não são fixos, não estão cristalizados no tempo ou no espaço. São transformados (subvertidos, rasurados, pintados de branco) e transpostos para palavras de ordem gritadas em protestos públicos, para dar nome a coletivos ou mobilizações sociais ou em fotografias que se multiplicam pelas redes sociais. São vozes dissidentes e indisciplinadas, desordenando, ressignificando e desafiando uma visão de cidade-mercado. São também um barómetro das tensões que se dão neste embate, 
revelando contradições entre centro e periferia, residente e viajante, proprietário e inquilino, governantes e povo.

Ainda que aparentemente, se trate de um protesto silencioso, estas imagens produzem ruídos que se transformam em ecos: são memória das resistências e impulso para lutas futuras. São imagens locais, sem deixarem de refletir problemas globais (Colomb \& Novy, 2017). Marcam o território, povoando-o de aspirações e indignações. O palco destas contra-visualidades é o lugar por onde circulamos para regressar às nossas casas, onde nos deslocamos para chegar aos nossos empregos, onde nos reunimos nos tempos de lazer, onde nos manifestamos por mais e melhor justiça. Revelando-se como "linguagens de resistência, de afronta, de crítica ou simples gozo, desafiando as convenções e a ordem visual da paisagem urbana", estas inscrições cumprem "funções de natureza estética, política, ideológica ou cultural, ao abrigo do espaço público de comunicação mais democrático: a rua”. (Campos, 2012: 75) Descodificar a cidade estará, portanto, também nesta arte de ler e escutar os seus muros. 


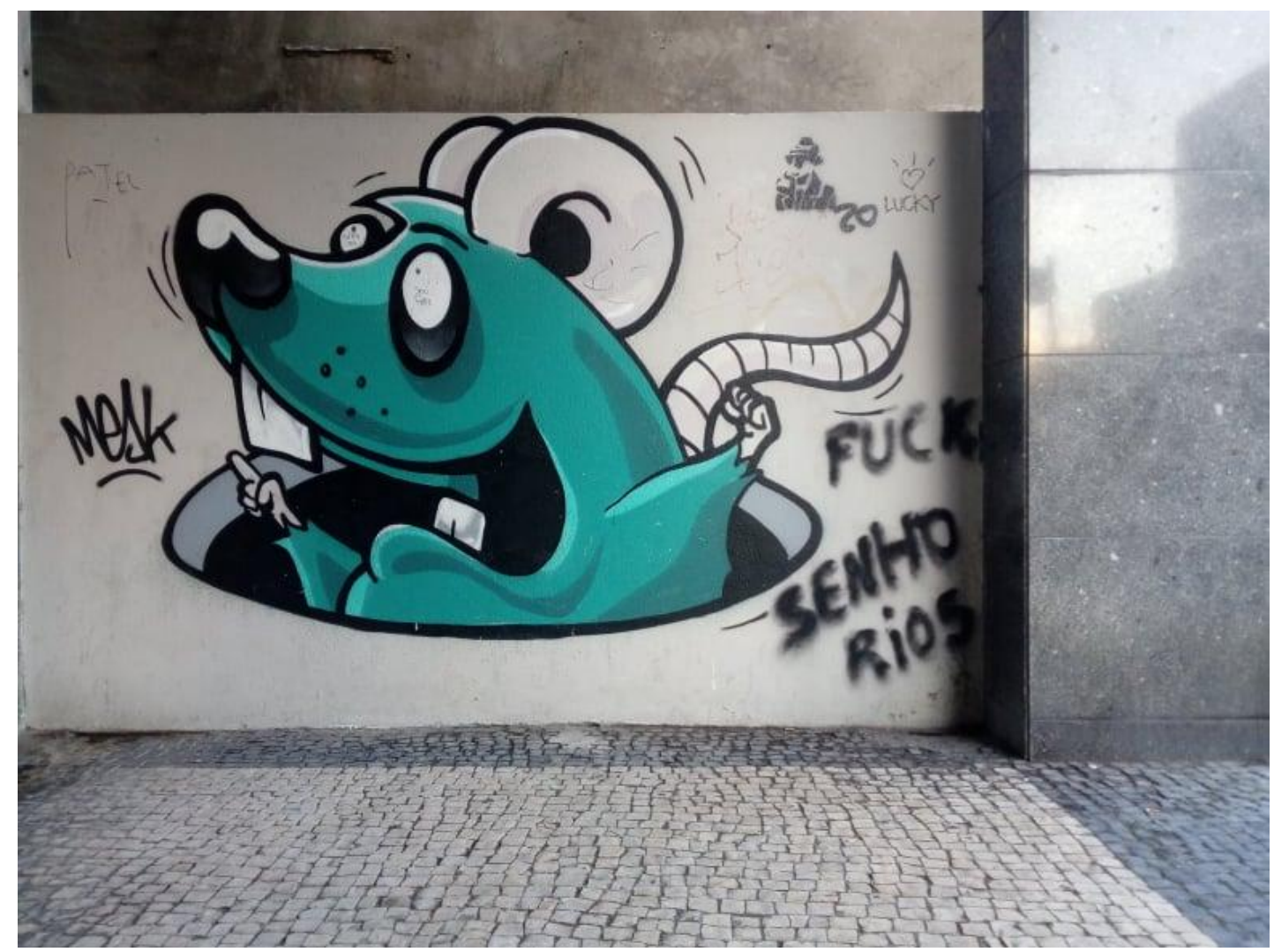

1. Rua Gonçalo Cristovão | Grafitti do street artist Mesk junto a um corredor de prédios cujos moradores/as foram quase todos/as despejados num curto espaço de tempo.

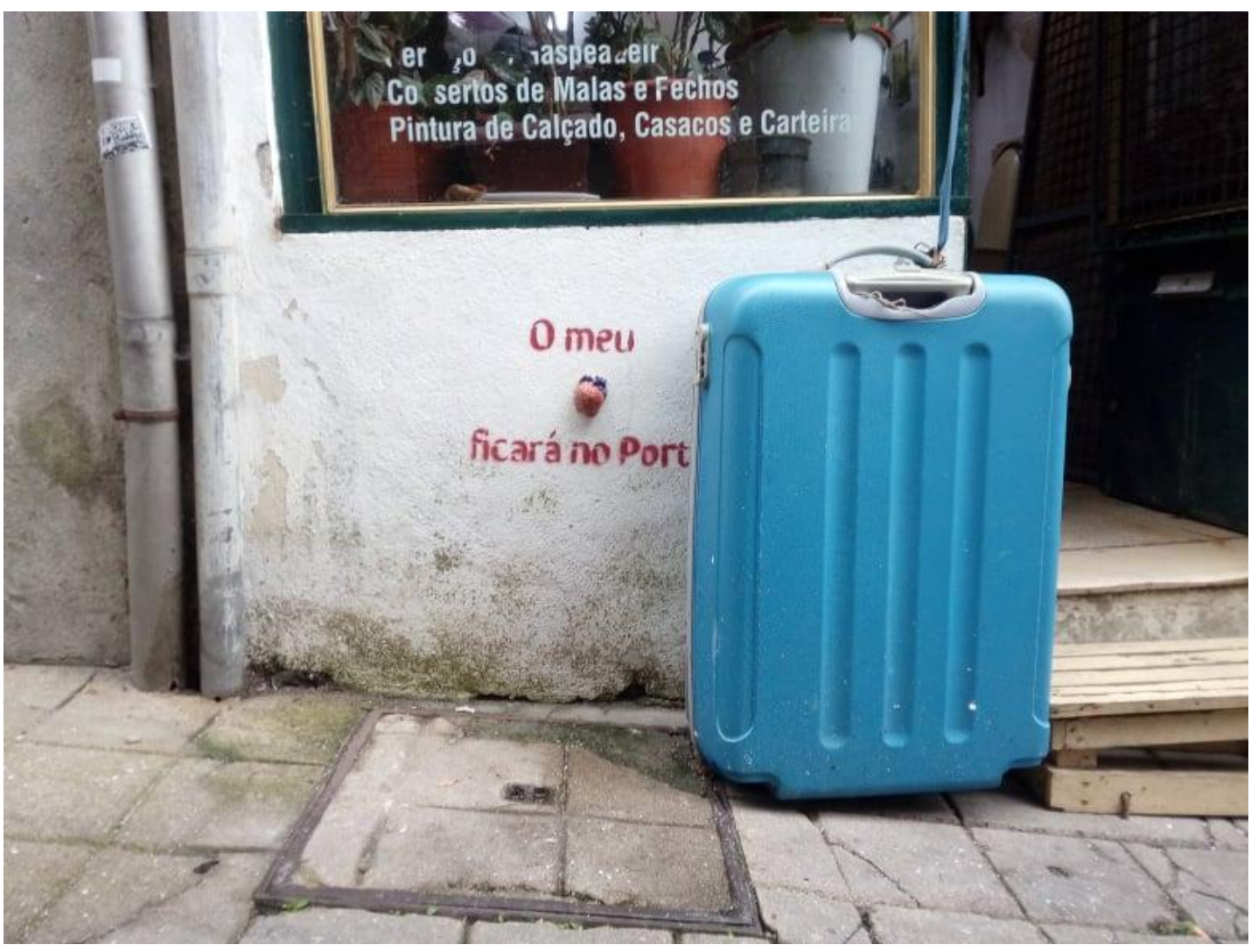

2. Rua Cimo de Vila | "O meu coração ficará no Porto", uma intervenção em cerâmica do artista 3 Pontinhos, no centro histórico da cidade onde ainda resiste parte do comércio tradicional. 


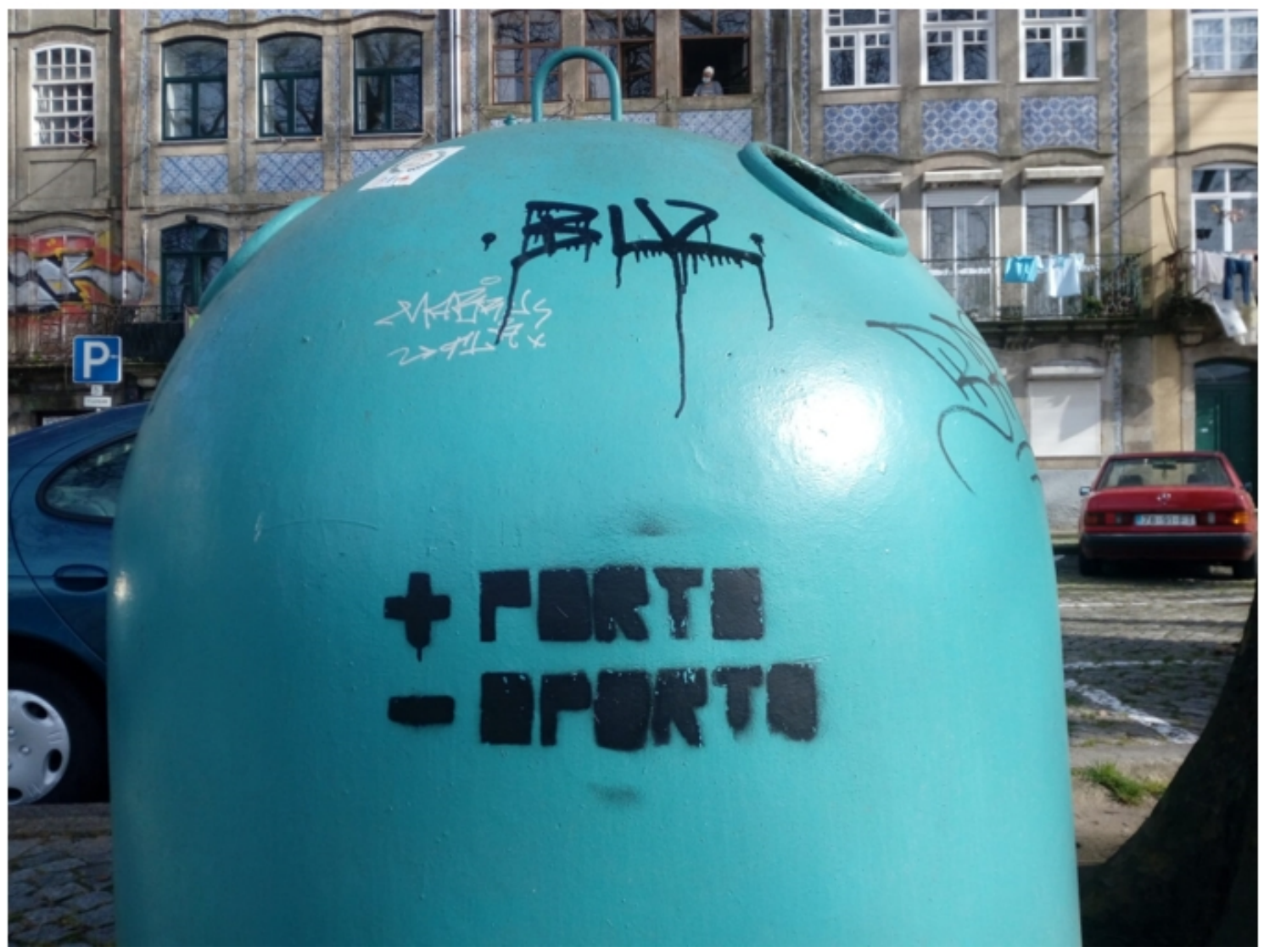

3. Passeio das Virtudes | Stencil pintado num vidrão, com o trocadilho "Mais Porto, menos Oporto" (nome pela qual a cidade é conhecida no estrangeiro).

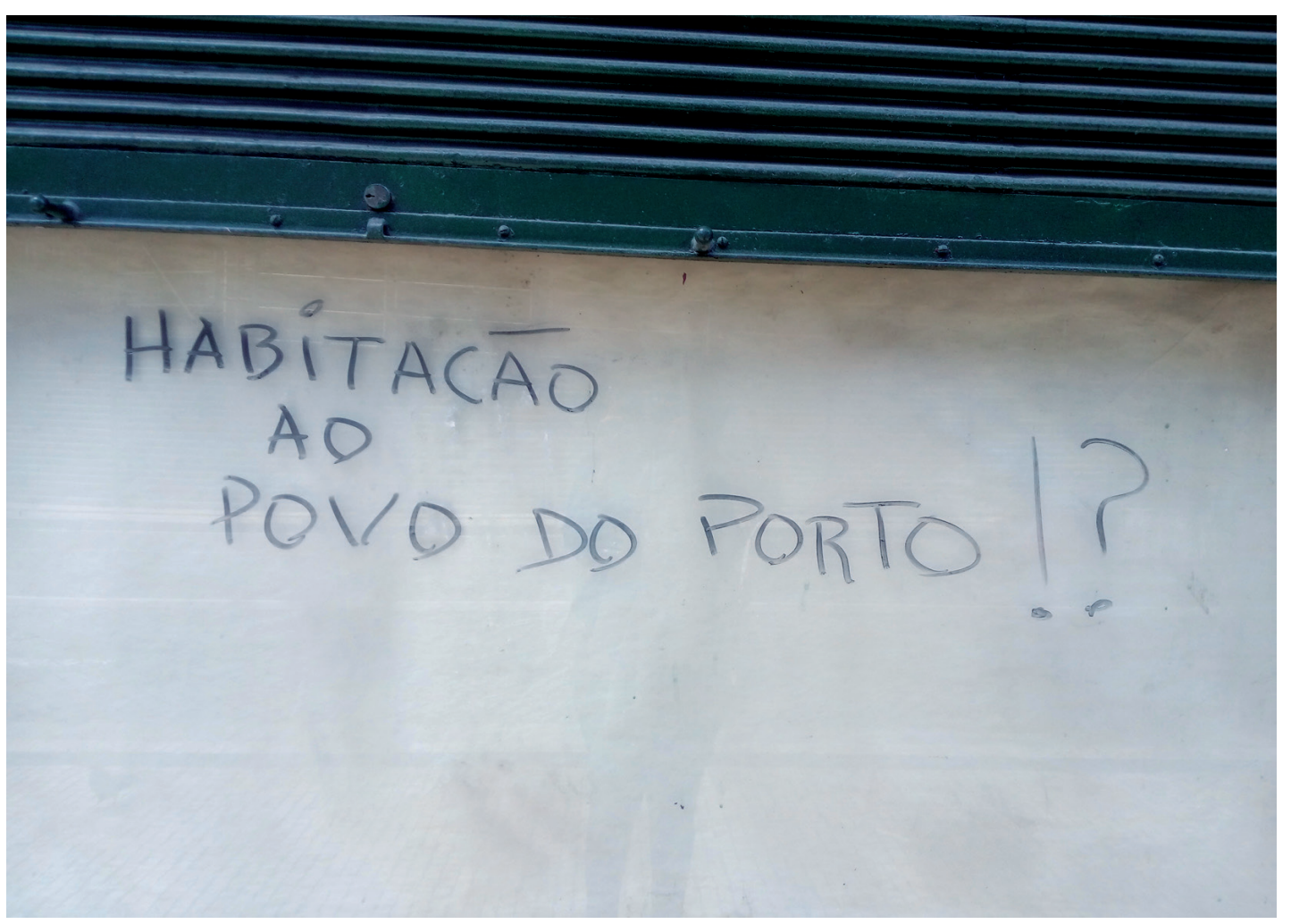

4. Rua Sá da Bandeira | Inscrição a marcador num espaço comercial encerrado, numa das ruas mais icónicas da cidade.

Iluminuras, Porto Alegre, v. 22, n. 56, p. 278-293, junho, 2021. 


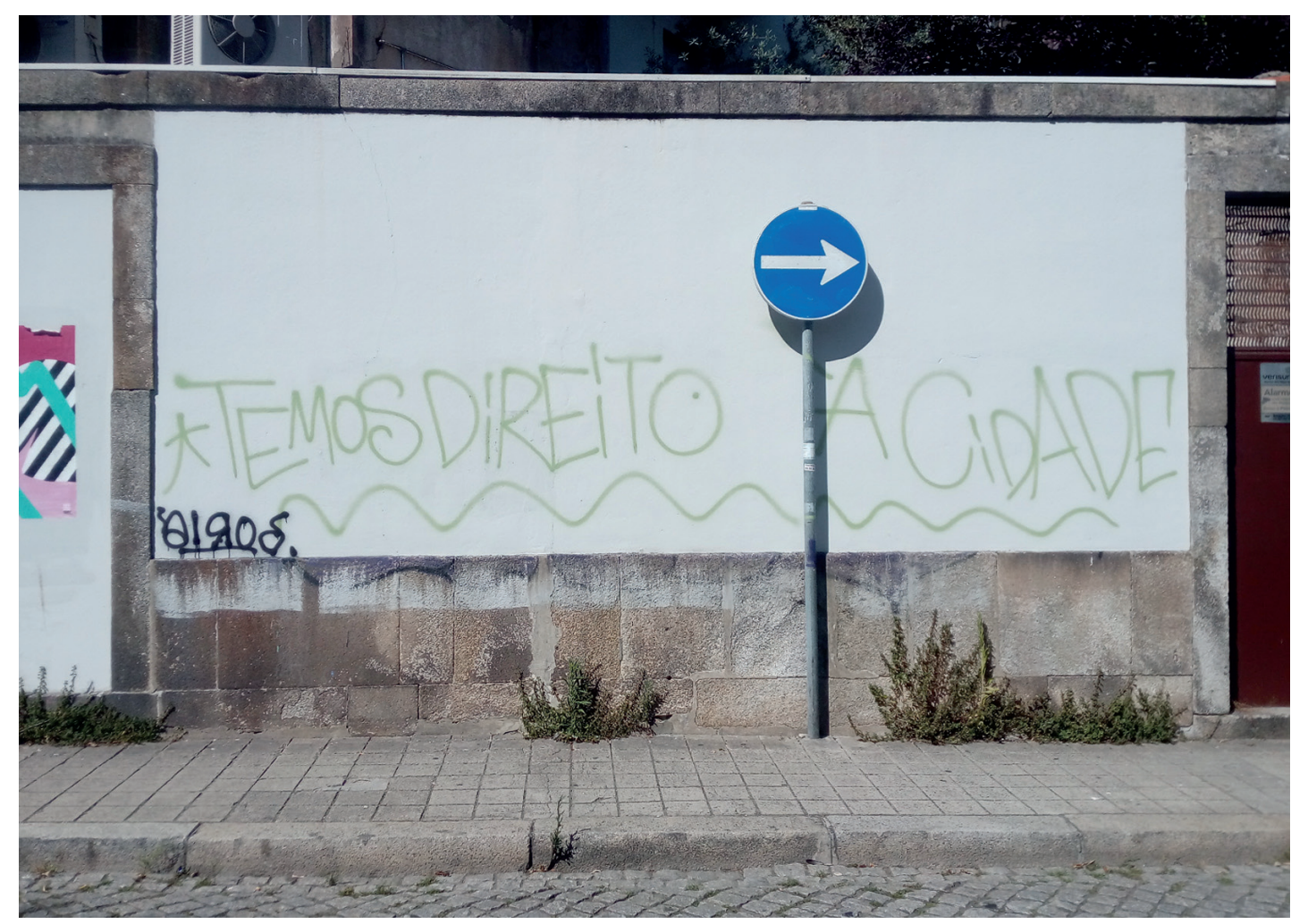

5. Rua de São Vítor | Grafitti junto ao bairro onde se concentram mais artistas, dada a proximidade com a Faculdade de Belas-Artes.

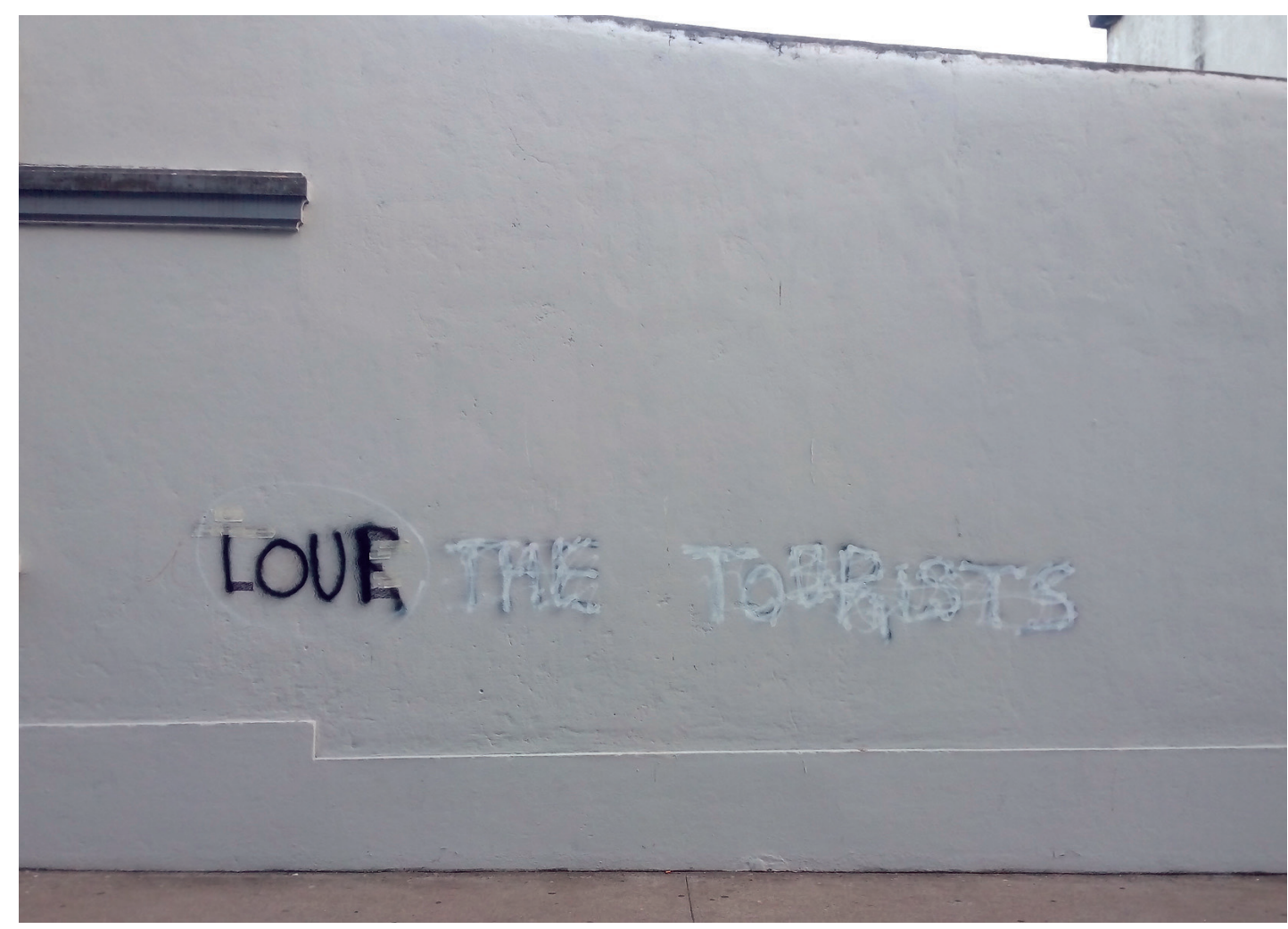

6. Rua Morgado de Mateus | Intervenção irónica "Love the tourists” (com as letras rasuradas).

Iluminuras, Porto Alegre, v. 22, n. 56, p. 278-293, junho, 2021. 


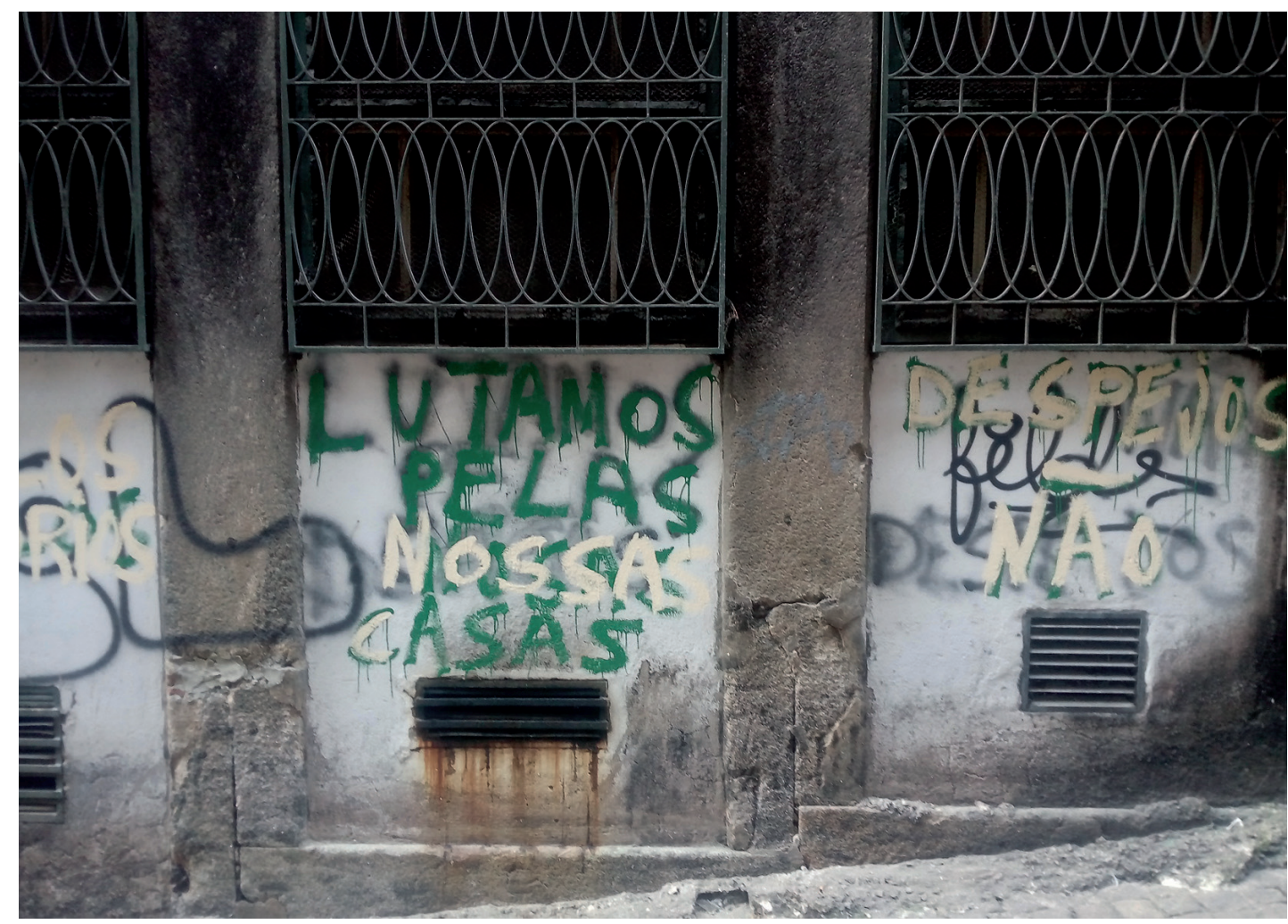

7. Rua dos Mercadores | Um dos muitos grafittis encontrados nesta rua, numa altura em que várias casas de alojamento local se erguiam lado a lado com edifícios abandonados.

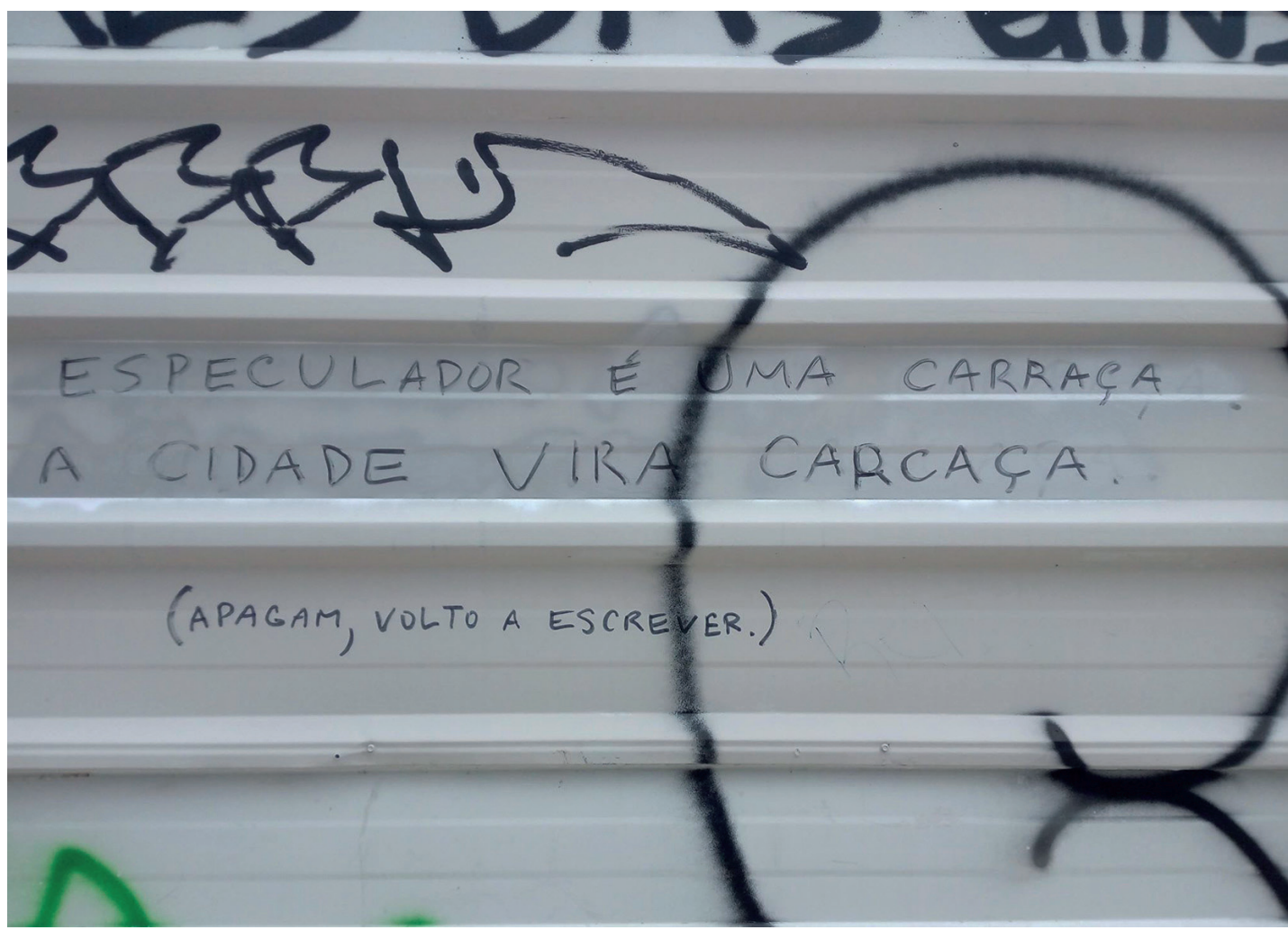

8. Rua Formosa | Mensagem insistente contrariando a efemeridade própria das inscrições de rua, escrita no taipal de umas obras paradas há vários anos.

Iluminuras, Porto Alegre, v. 22, n. 56, p. 278-293, junho, 2021. 


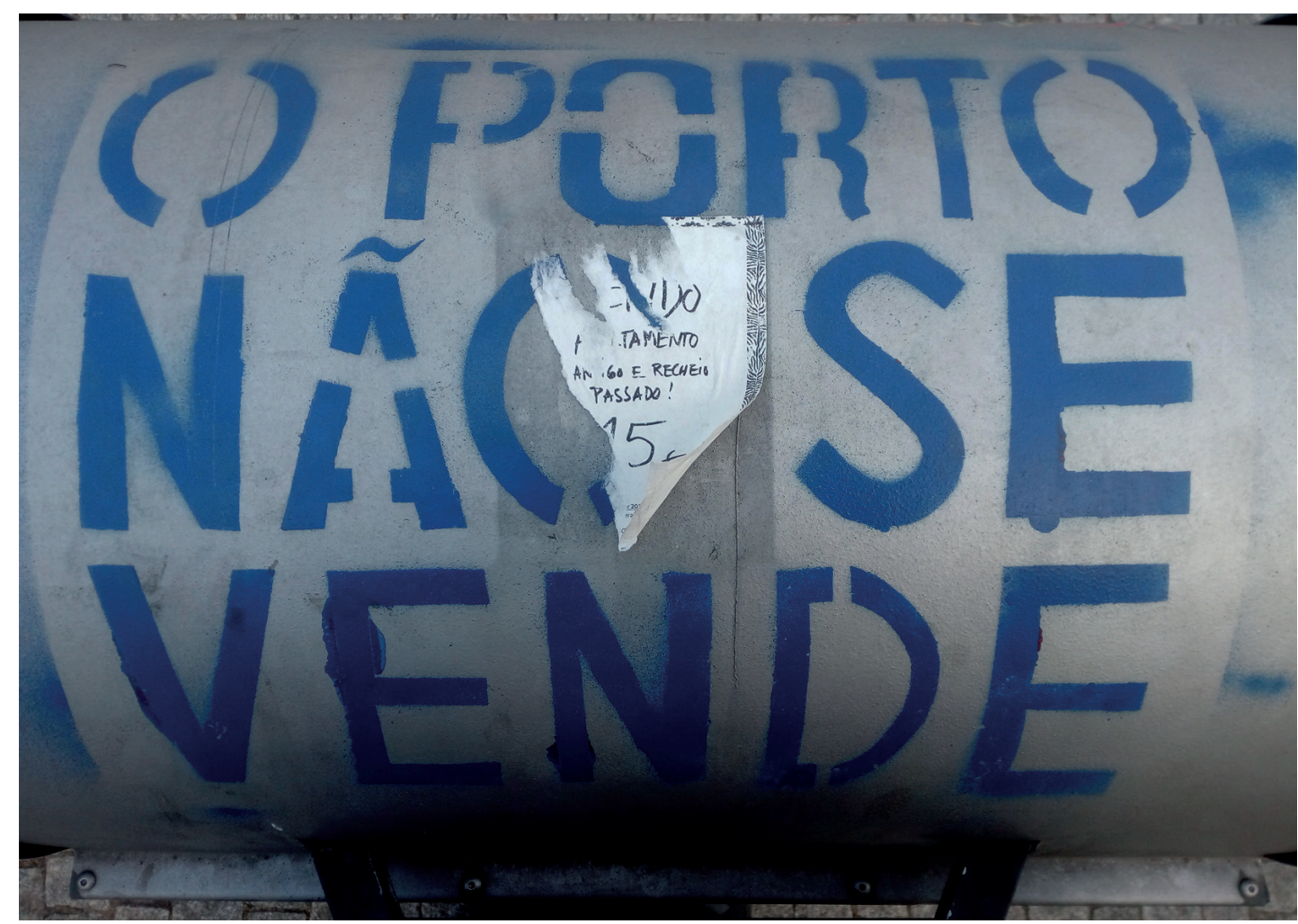

9. Rua das Fontainhas | Stencil num contentor de reciclagem, encontrado em vários pontos da cidade e que deu nome a uma organização coletiva e a uma manifestação pública.

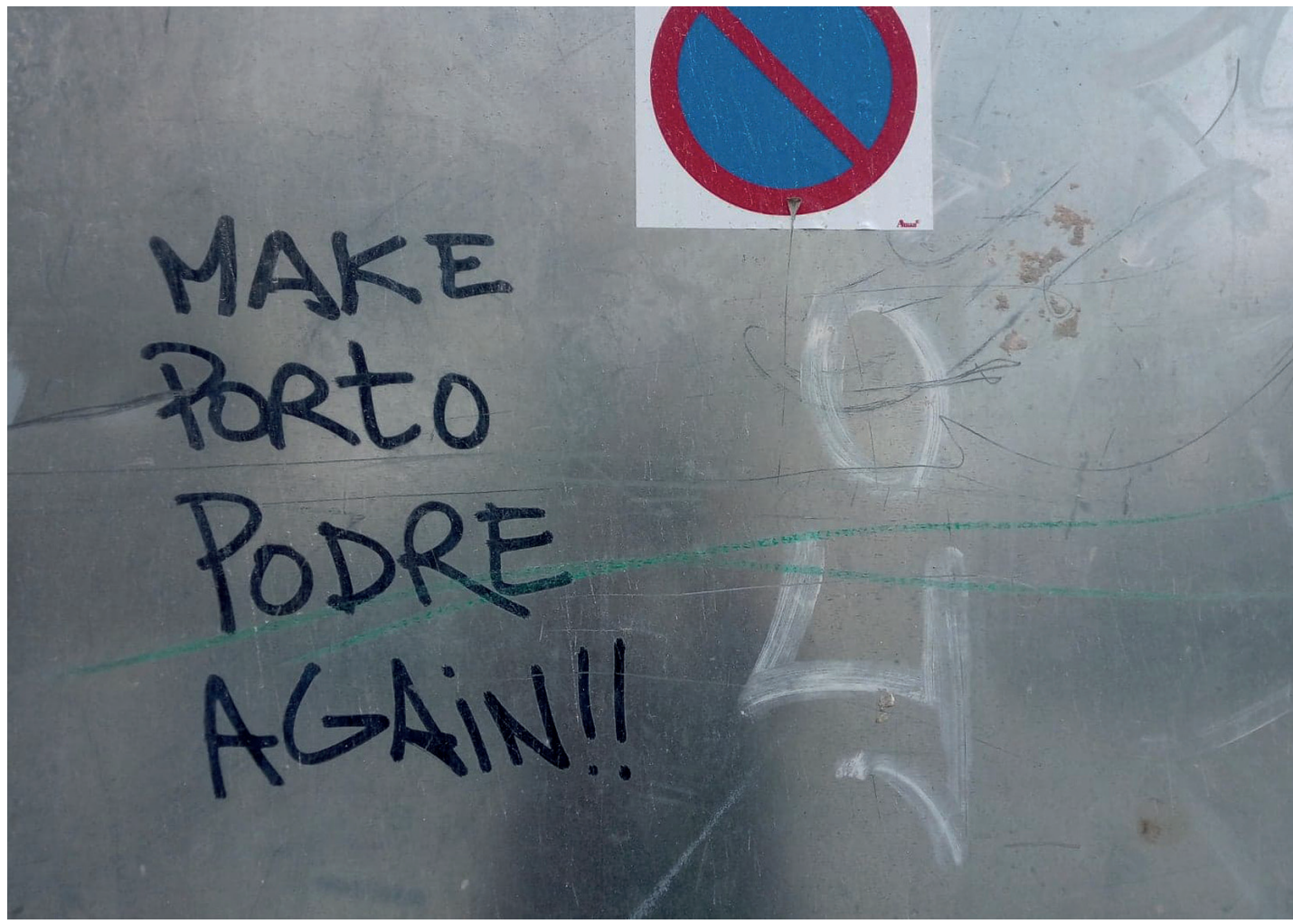

10. Rua de S. Rosendo | Slogan bastante disseminado pela cidade que reporta para um imaginário de um Porto "podre", mas genuíno e tradicional, de outrora. 


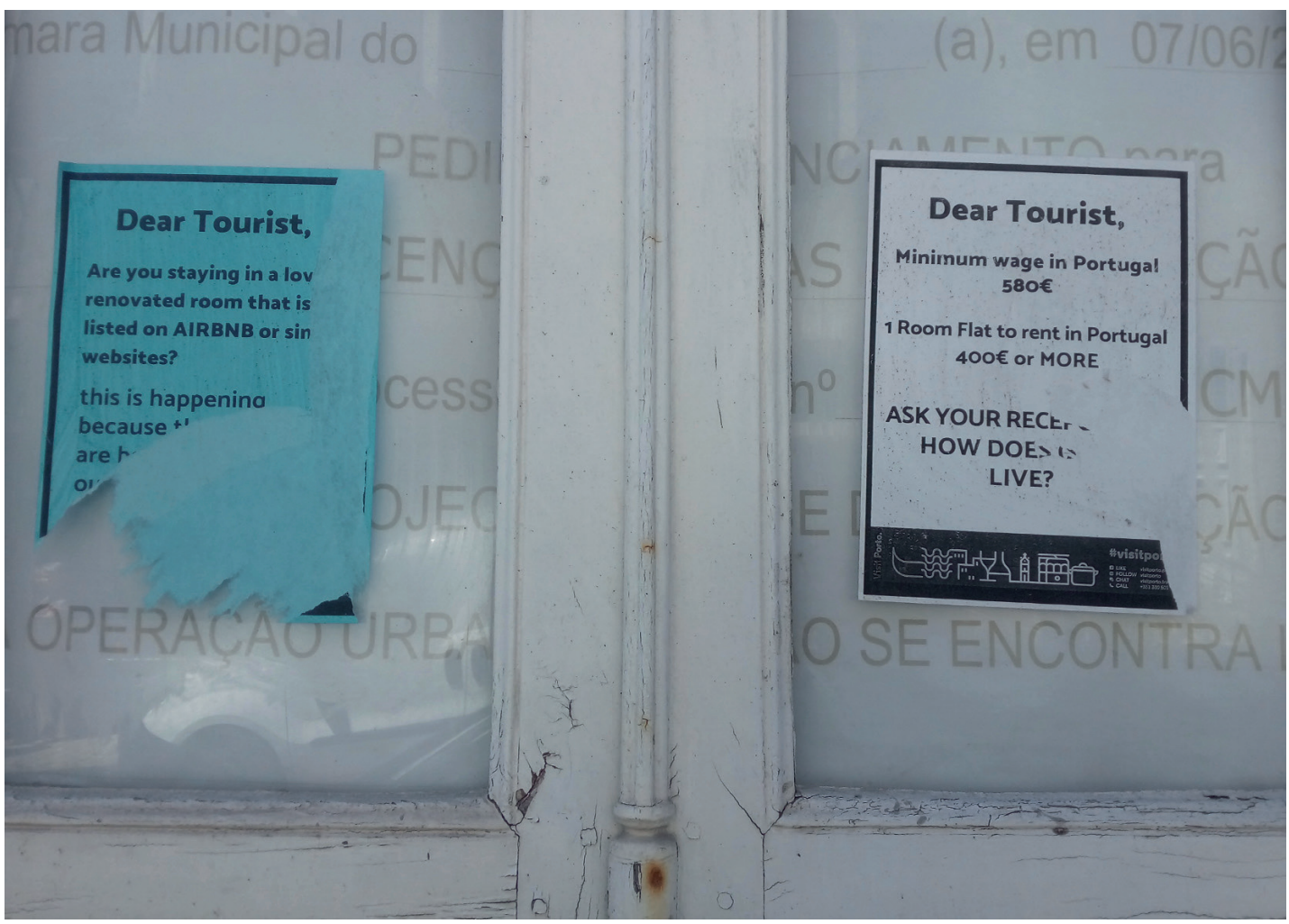

11. Rua do Almada | Cartas dirigidas aos turistas apontando as desigualdades sociais que estão por detrás da indústria do turismo: "Pergunte ao seu recepcionista como é que ele vive".

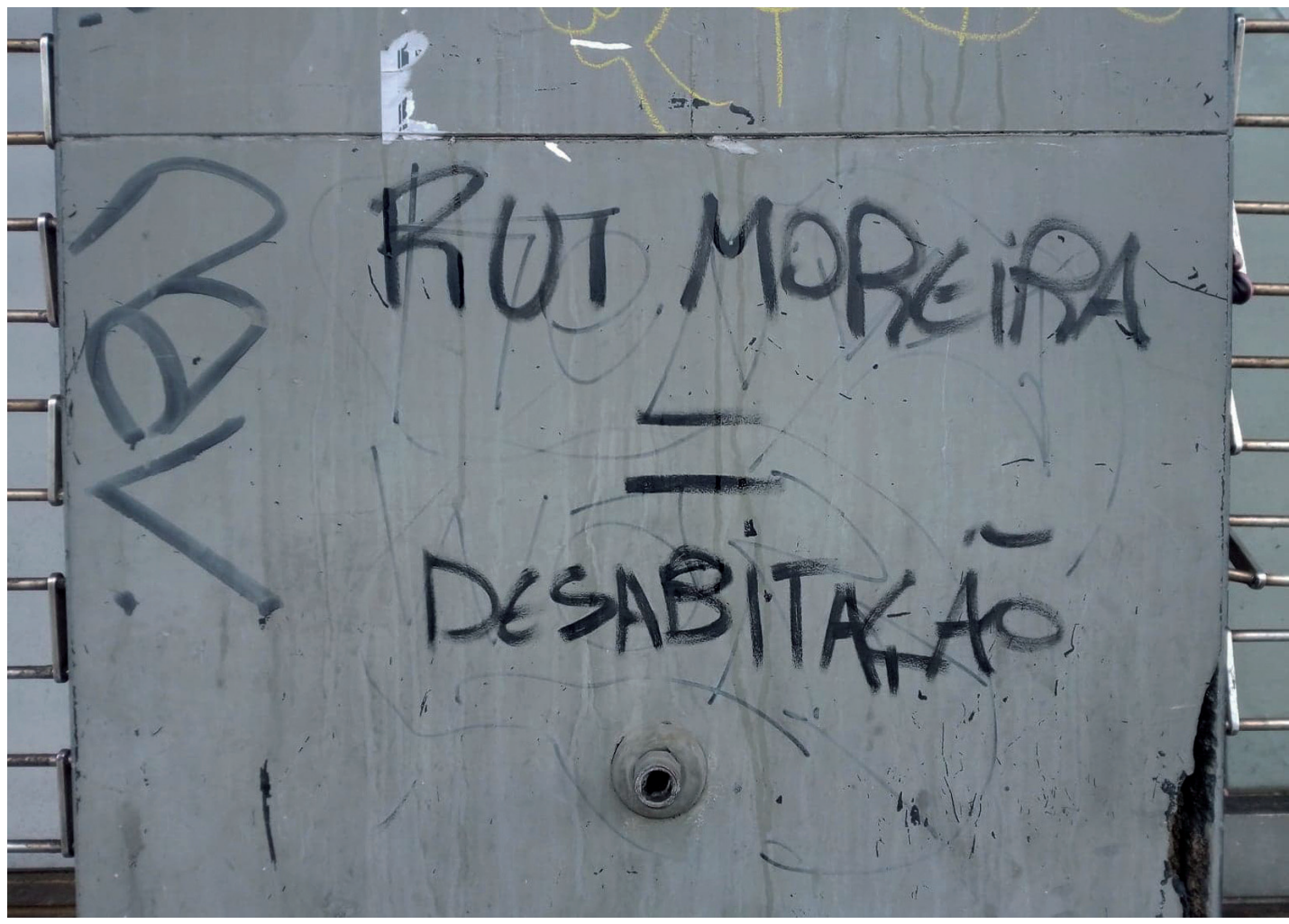

12. Rua Nova de Alfândega | Mensagem destinada ao presidente da Câmara Municipal do Porto a quem acusam de promover políticas de "desabitação". 


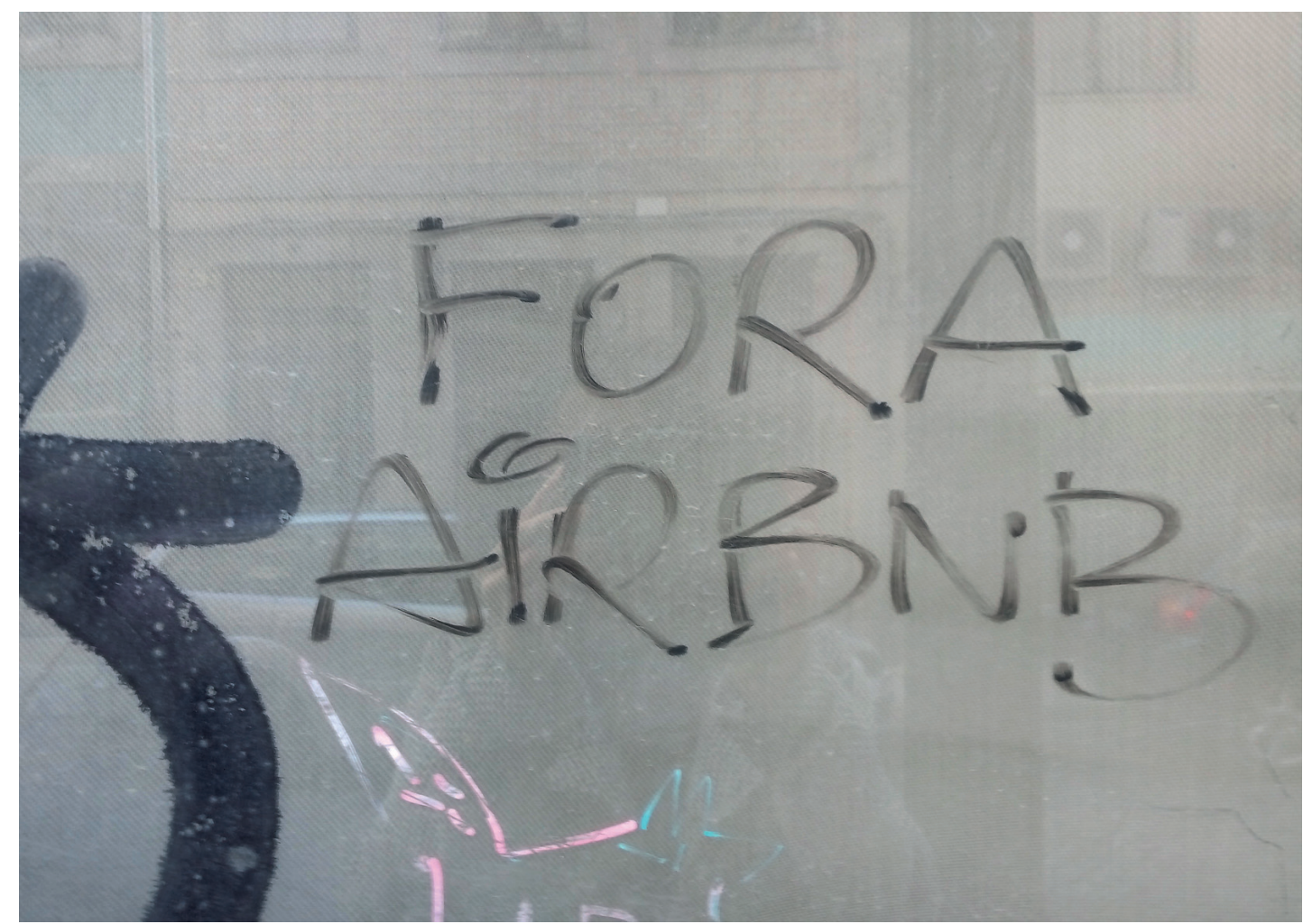

13. Rua da Alegria | Aviso escrito no vidro de uma superfície comercial desativada.

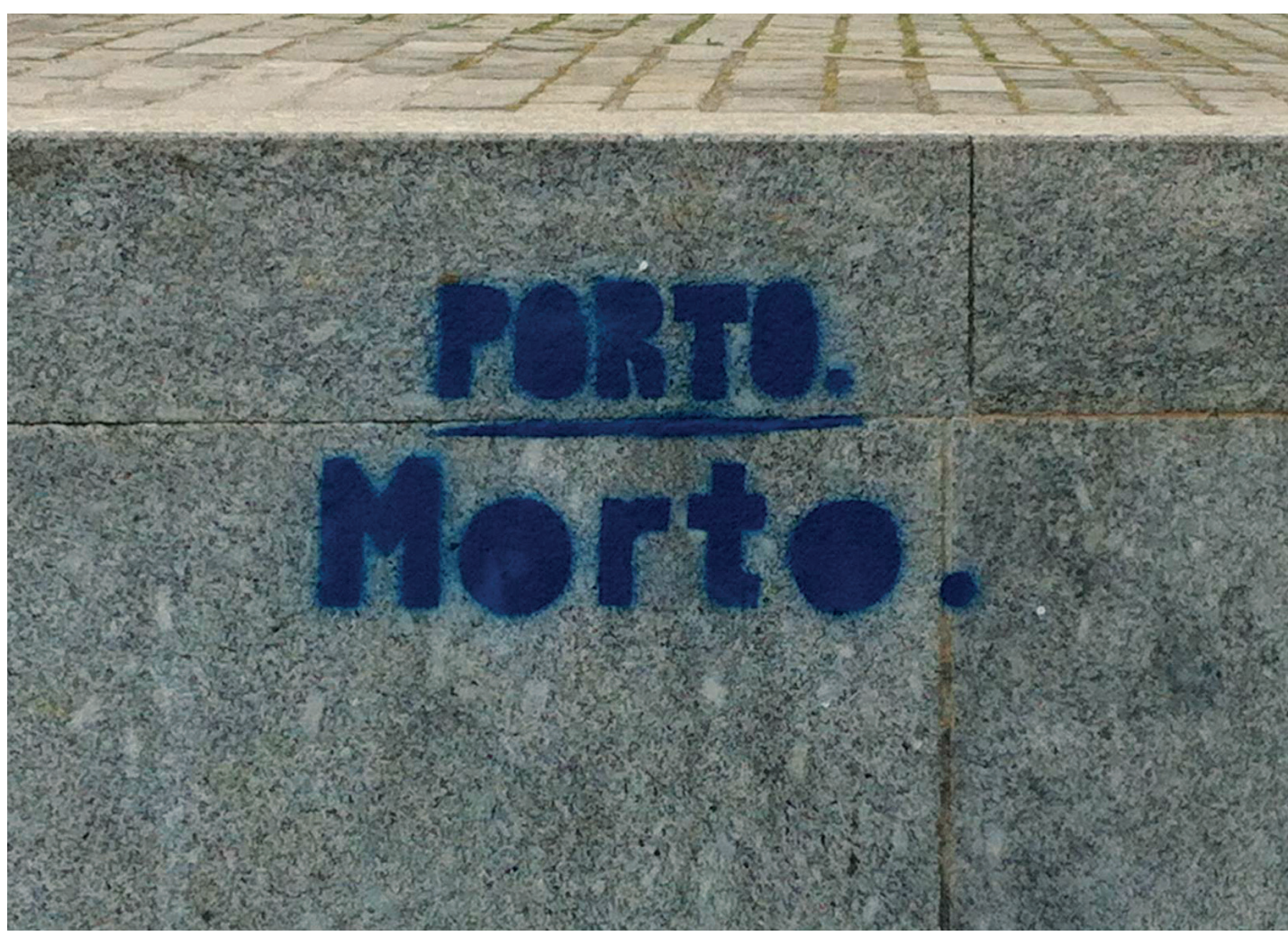

14. Largo Amor de Perdição | Trocadilho difundido em diferentes formatos (autocolante, stencil, grafitti, etc) que deu origem a uma queixa crime contra autor desconhecido, por parte do presidente da CMP. 


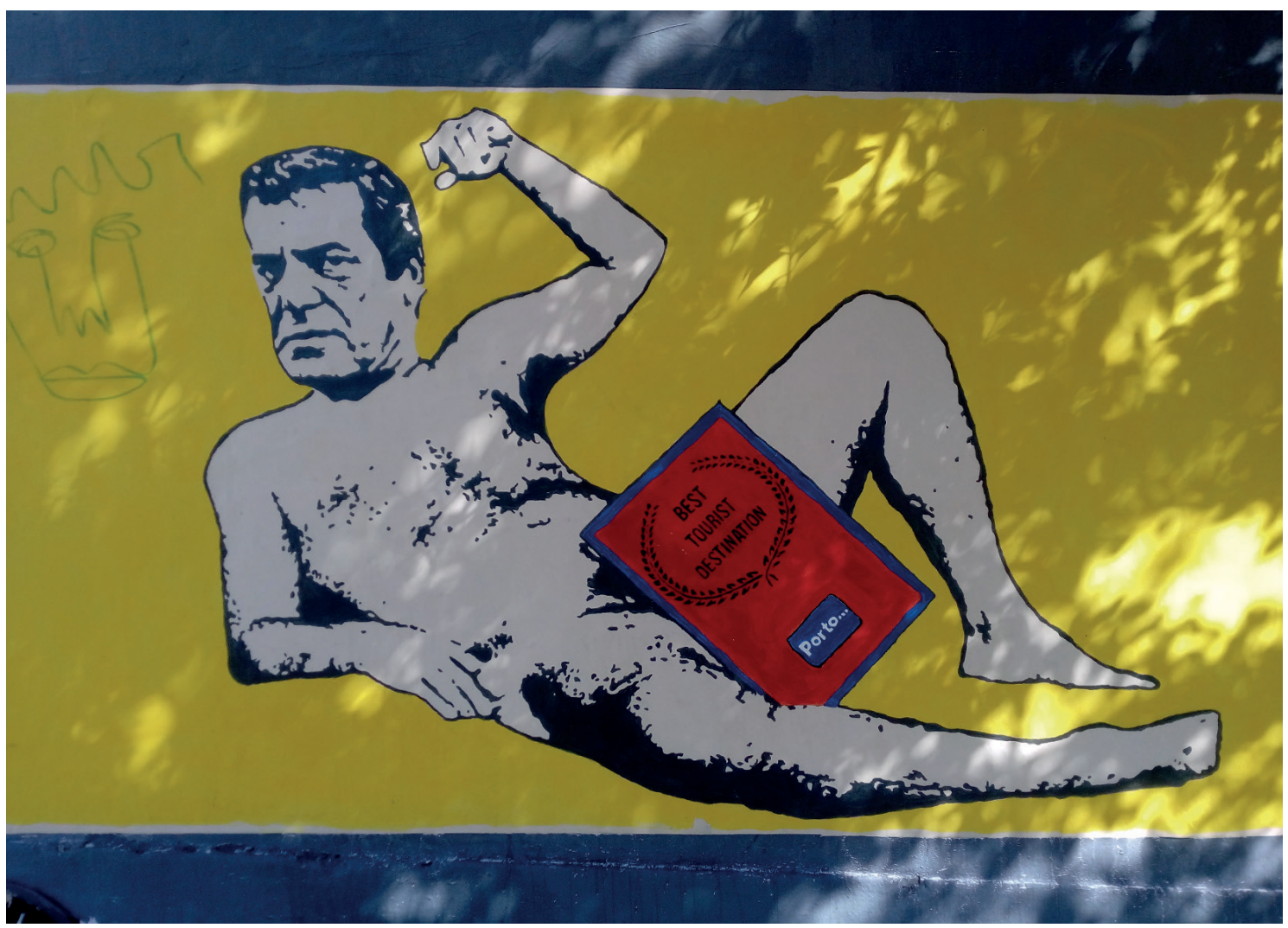

15. Praça dos Poveiros $\mid$ Mural do artista 3 Pontinhos caricaturando o presidente da CMP, numa das praças mais frequentadas pela cena cultural e artística.

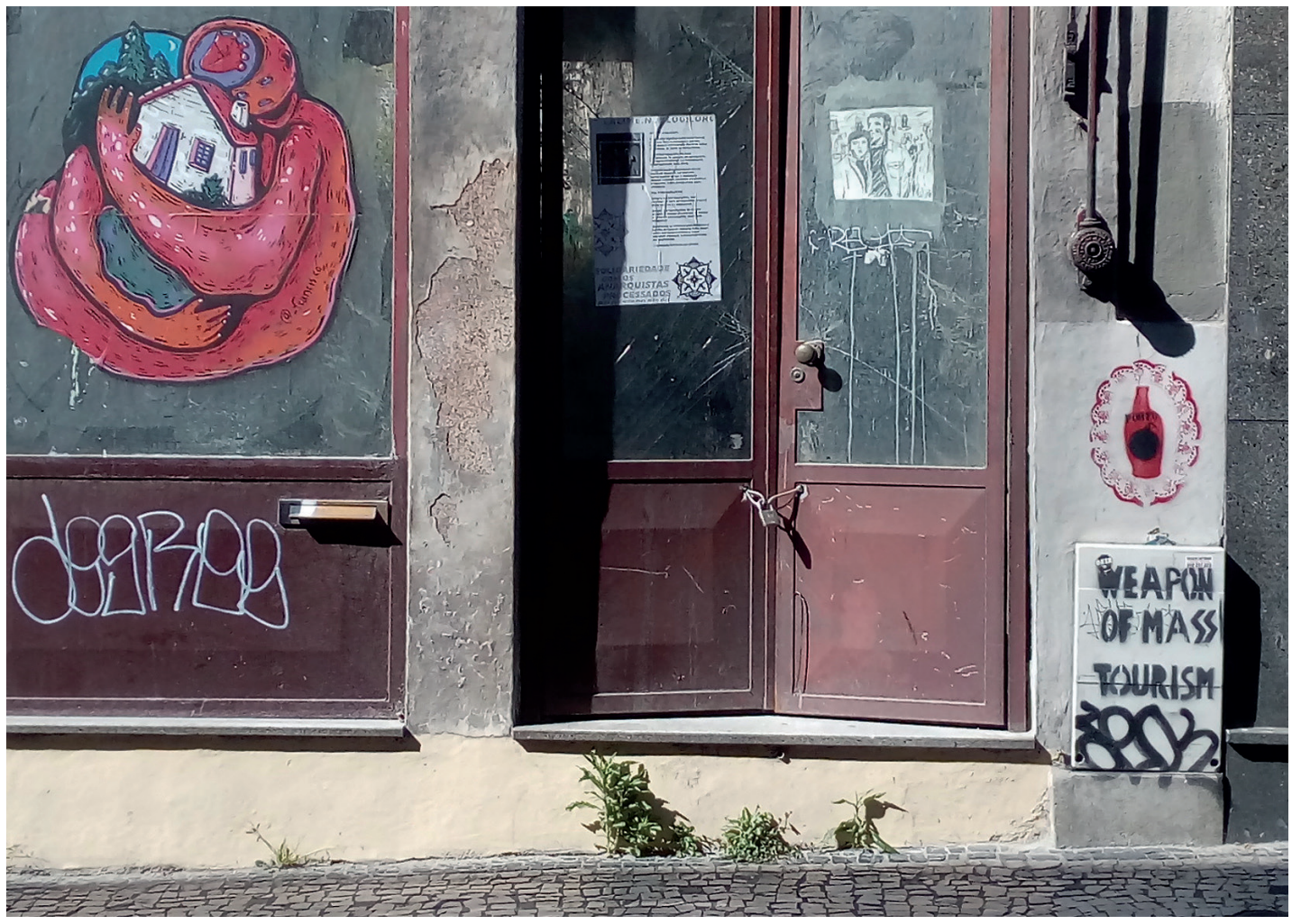

16. Rua Formosa | Várias intervenções numa fachada abandonada: um grafitti que reporta para a dimensão afetiva da habitação, uma bomba-relógio e uma alusão à "weapon of mass destruction". 


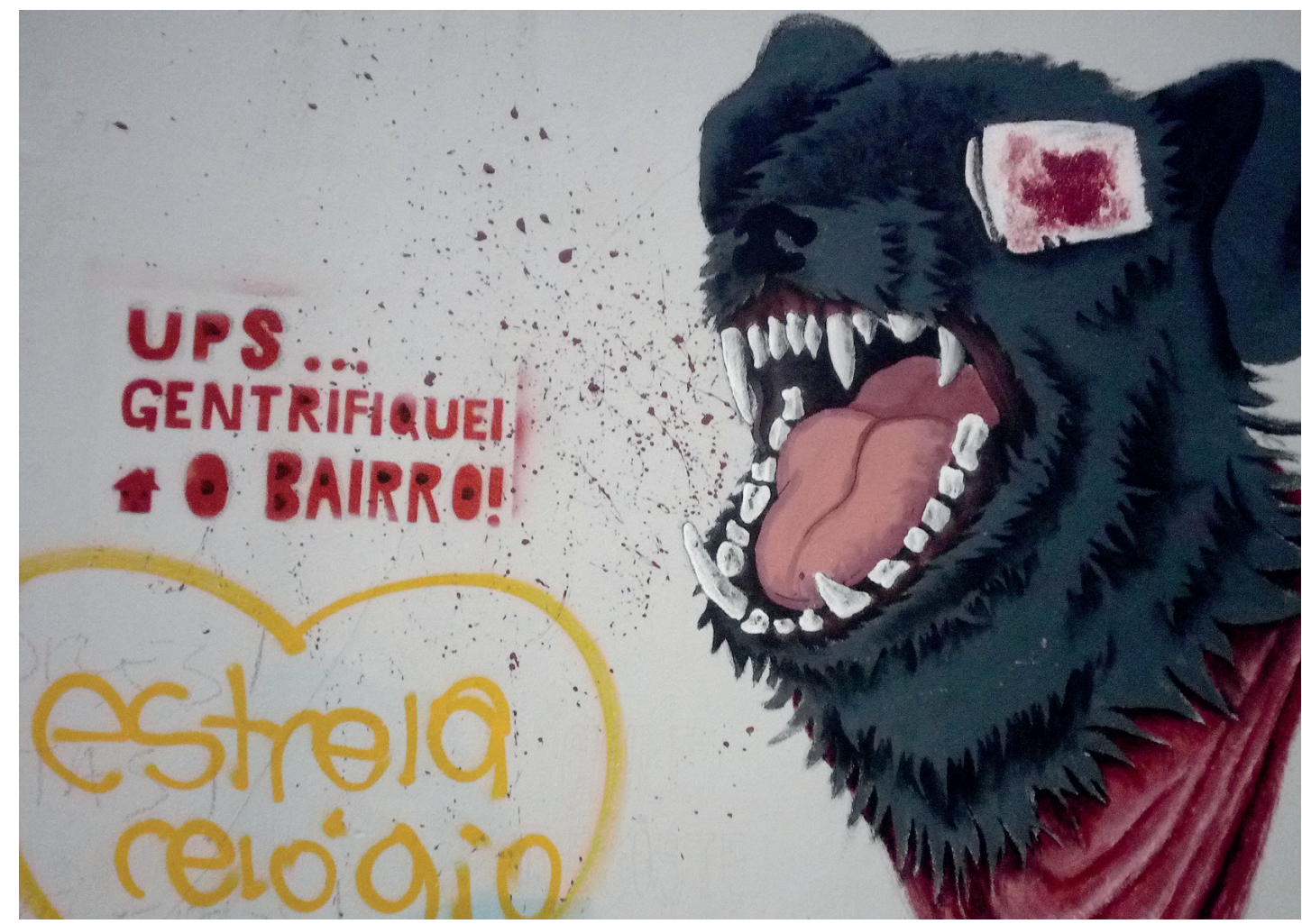

17. Rua Damião de Góis | Grafitti que parece insinuar a responsabilidade que muitos/as residentes (em particular, os artistas) têm no processo de gentrificação dos seus próprios bairros.

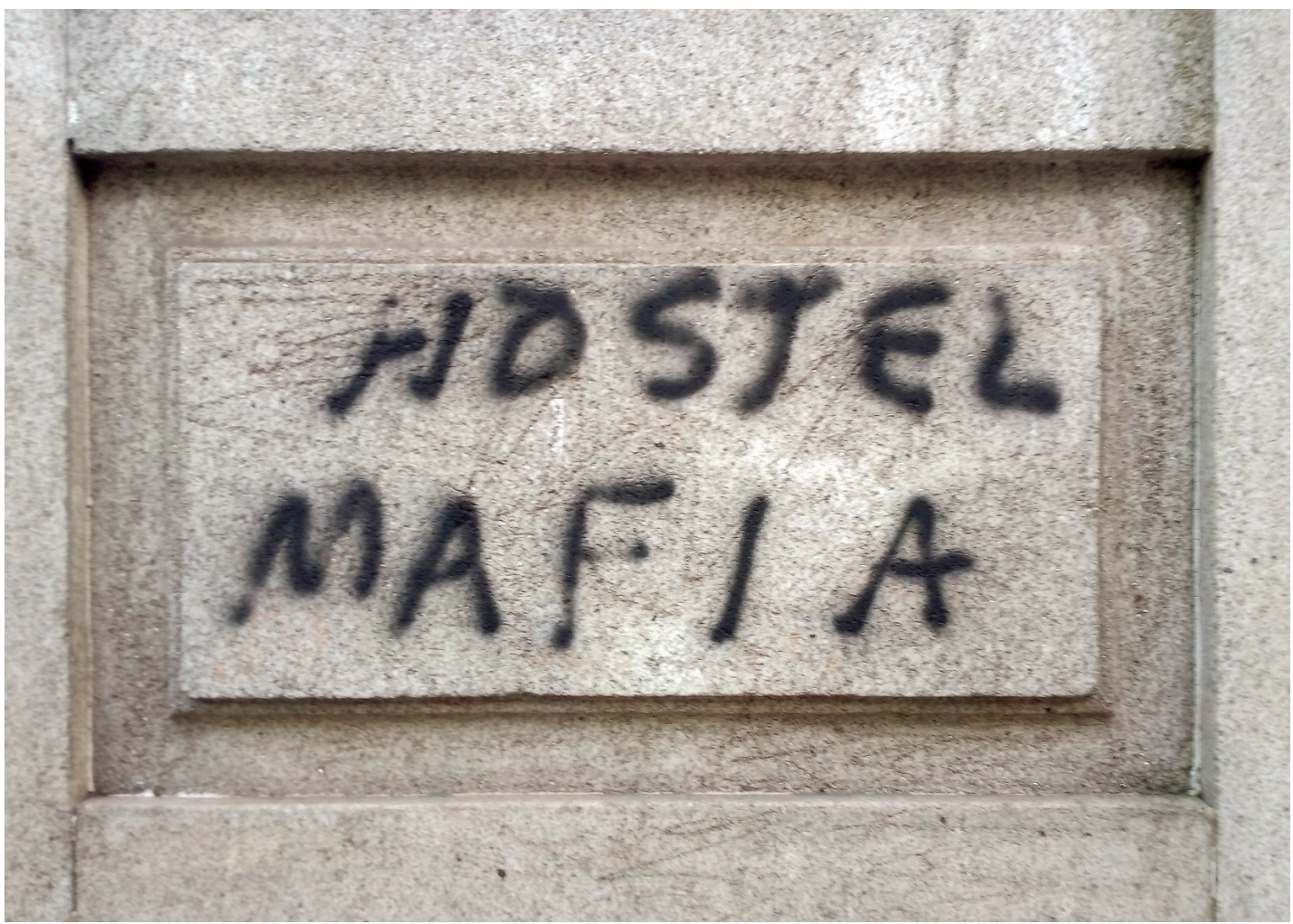

18. Rua D. João IV | Expressão pintada numa fachada de um prédio de renome, numa dos locais onde existem mais hotéis e AirBnBs. 


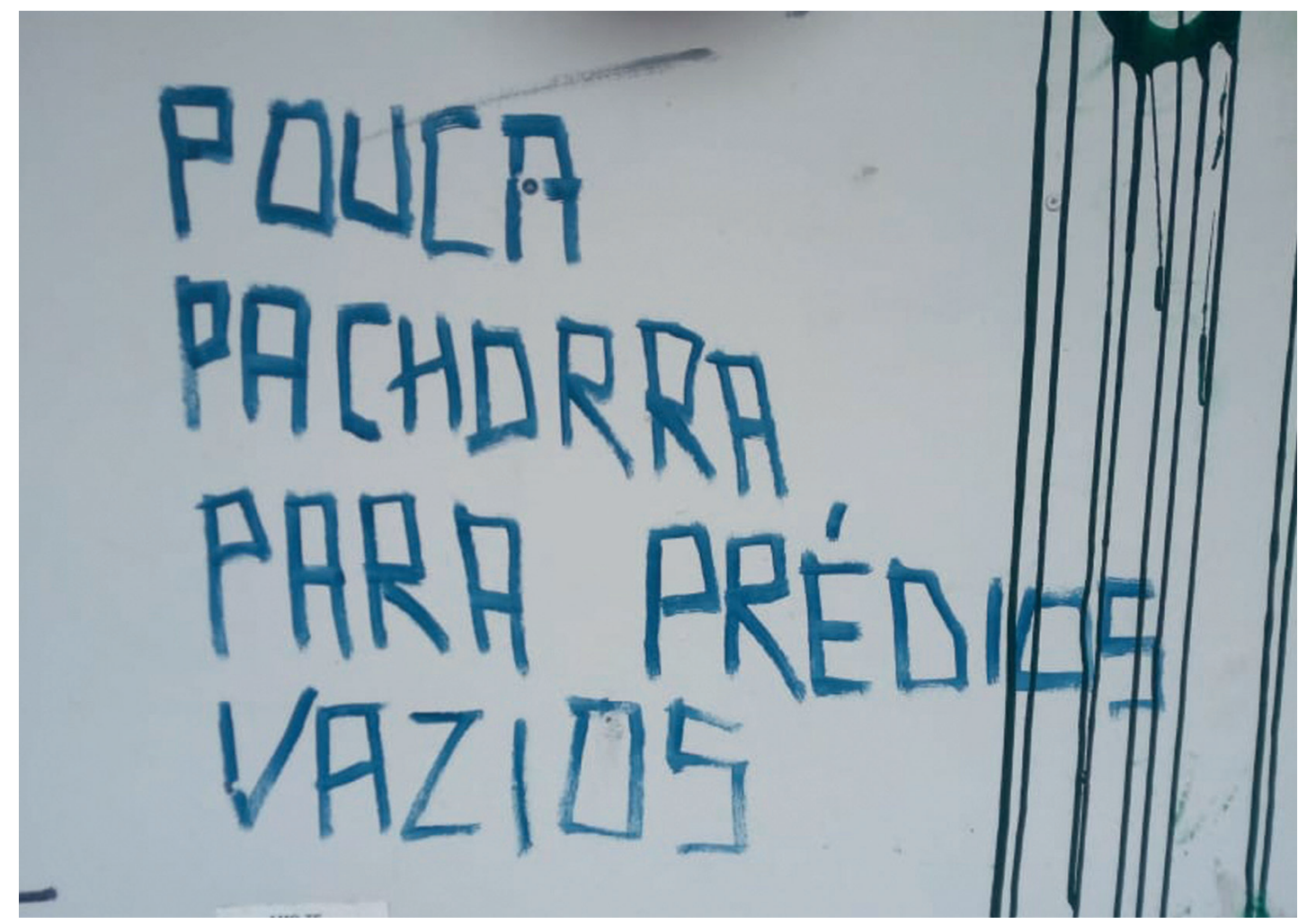

19. Rua de Santa Catarina | Mensagem escrita em letras garrafais na rua mais movimentada da cidade, criticando a existência de várias casas e espaços comerciais devolutos.

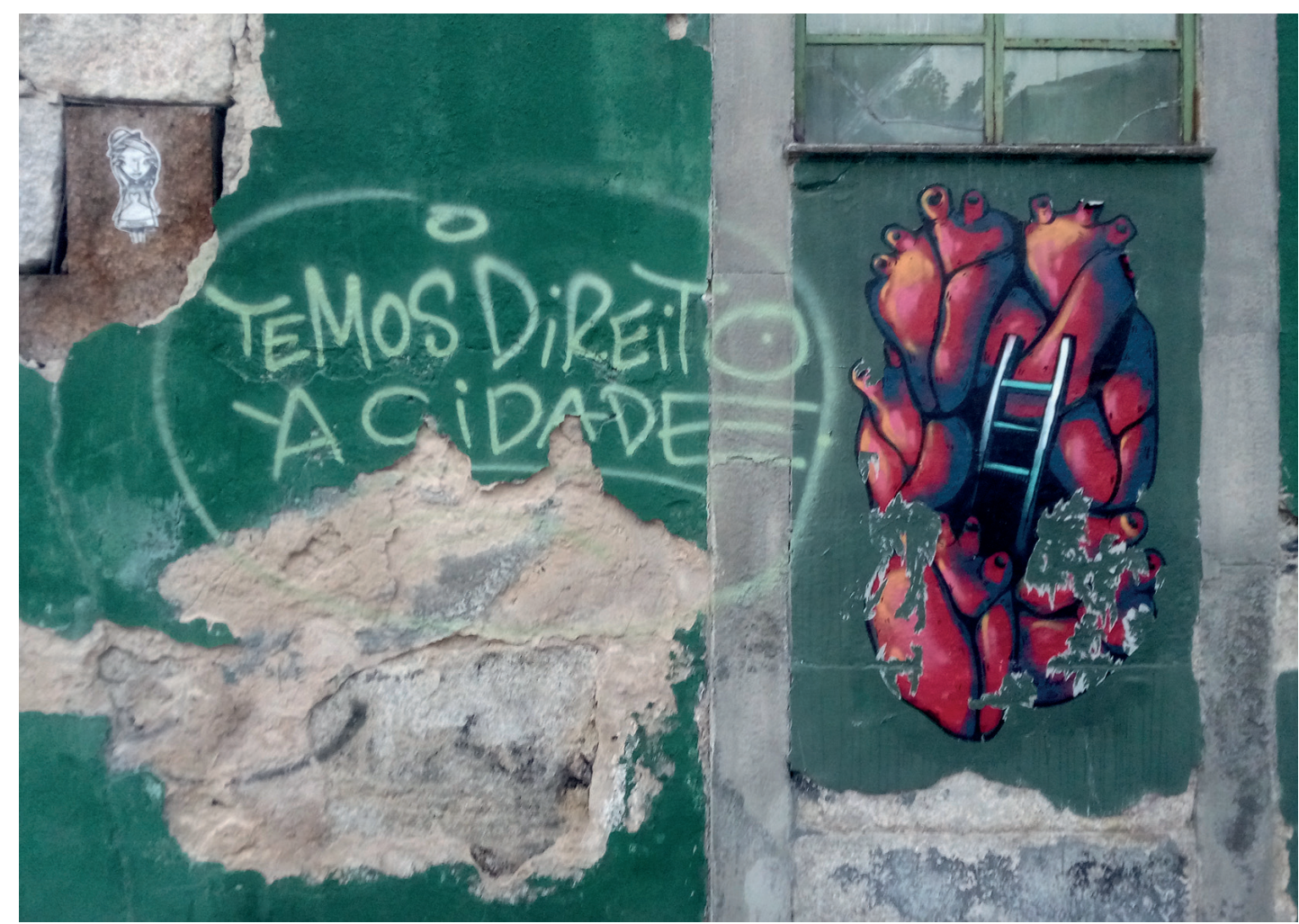

20. Largo do Camarão | Grafitti pintado numa casa em ruínas: uma escada entranhada num enigmático aglomerado de corações. 


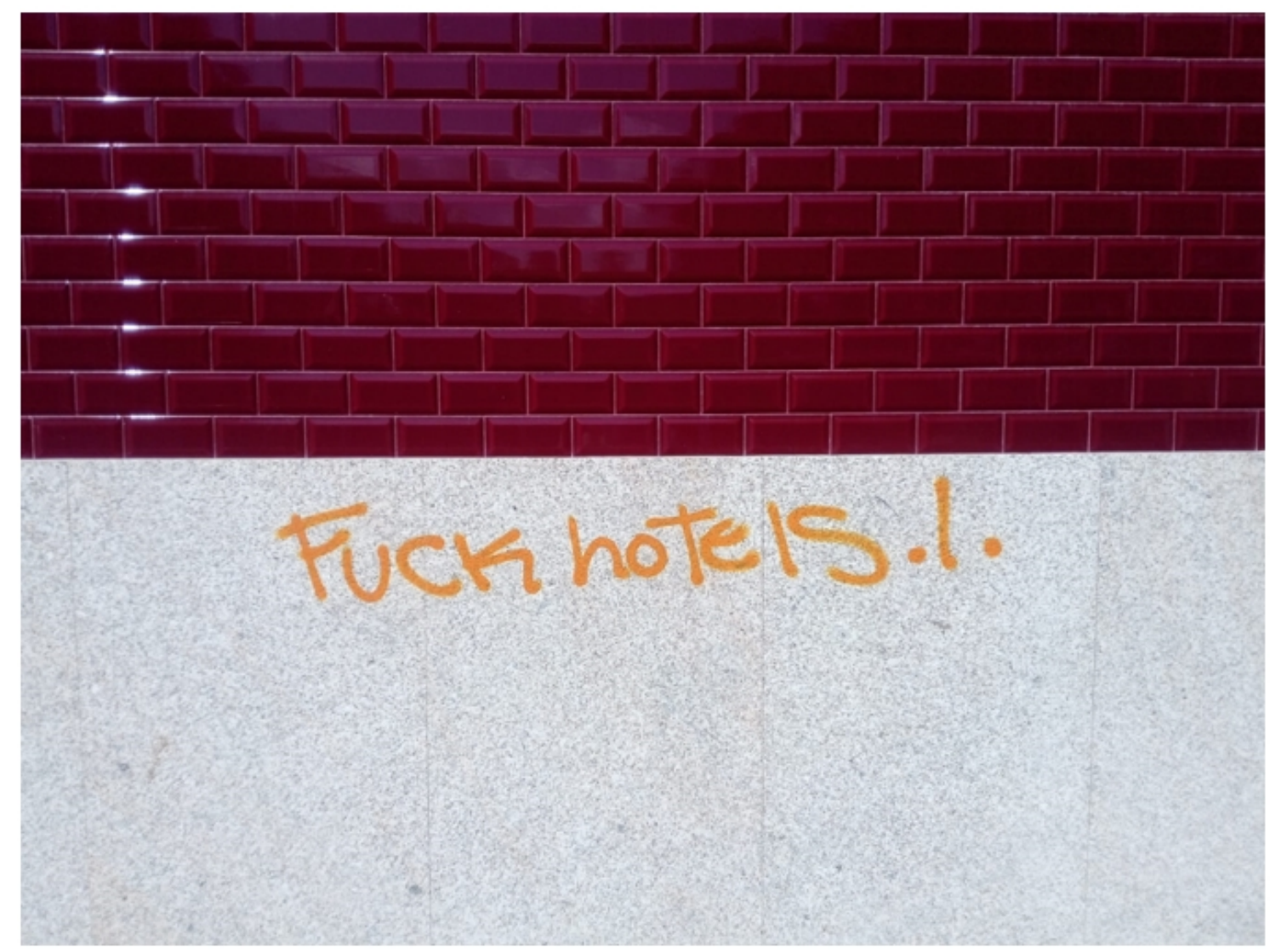

21. Passeio de São Lázaro | Mensagem direta e irada contra a profusão de unidades hoteleiras.

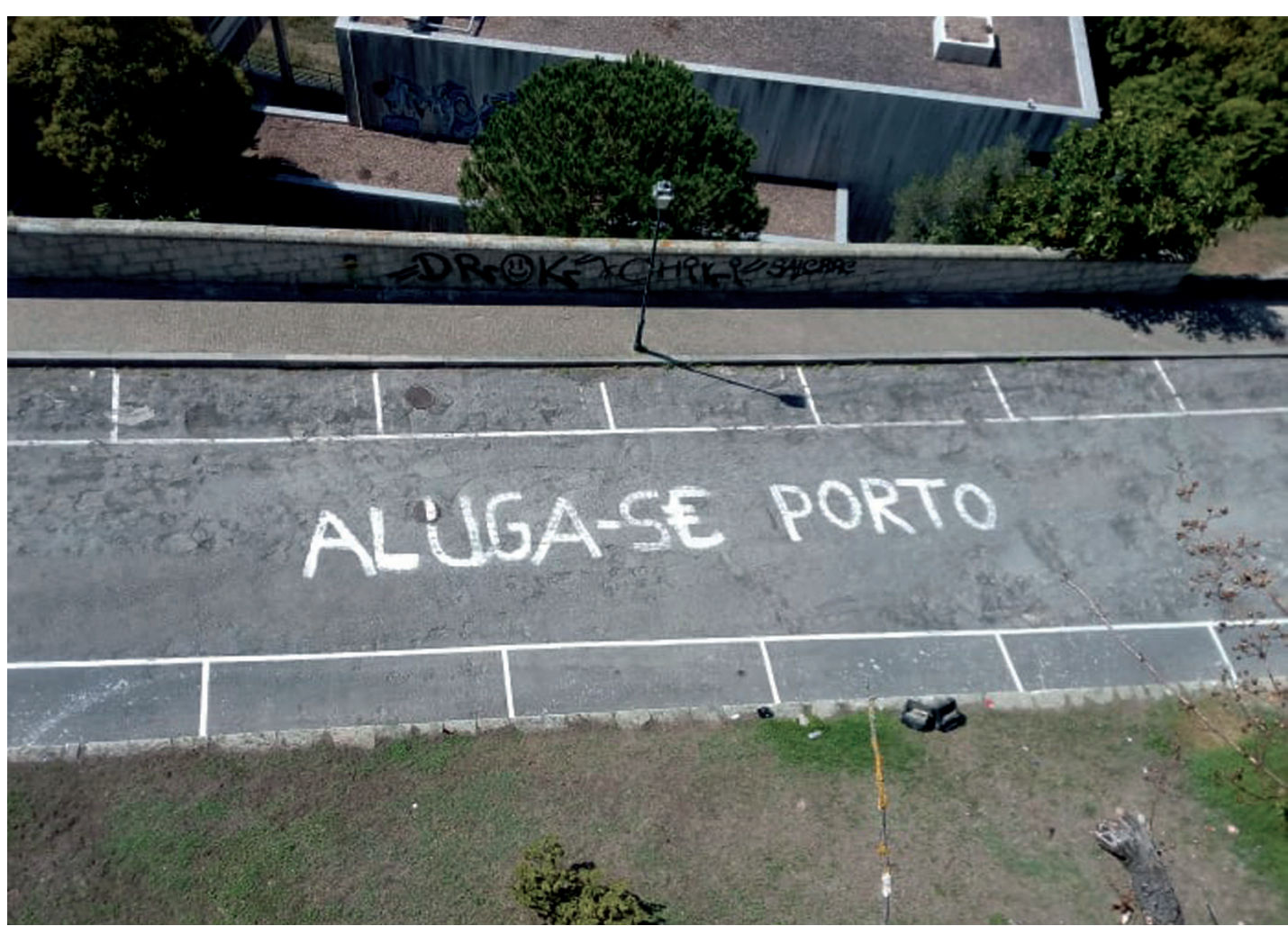

22. Calçada das Virtudes | Frase satírica (com o pormenor do E com o símbolo do euro) desenhada no pavimento de um dos lugares que mais atrai turistas e residentes.

Iluminuras, Porto Alegre, v. 22, n. 56, p. 278-293, junho, 2021. 


\section{REFERÊNCIAS}

ANTUNES, Gonçalo. O memorando da Troika e o mercado de habitação em Portugal. Working paper, de acesso reservado, 2019.

BARBOSA, Inês e LOPES, João Teixeira. Descodificar as paredes da cidade: crítica à gentrificação e luta pela habitação no Porto, Sociologia, 38, 2019.

CAMPOS, Ricardo. Paredes comunicantes: foto ensaio sobre espaço público e comunicação ilegal. Cadernos de Arte e Antropologia, $\mathrm{n}^{\mathrm{o}}$ 1, 73-76, 2012.

COLOMB, Claire e NOVY, Johannes. (Eds) Protest and Resistance in the tourist city. New York: Routlledge, 2017

CRARY, Jonathan. 24/7: o capitalismo tardio e os fins do sono. Lisboa: Antígona, 2018. FERNANDES, José A. Rio et al. O Porto e a Airbnb. Porto: Book Cover, 2018.

INGOLD, Tim e Vergunst, Jo Lee. Ways of Walking: Ethnography and Practice on Foot. London and New York: Routledge, 2008.

JANOSCHKA, Michael. Gentrificacion en Espana reloaded. Papers 60, Gentrificació i dret a la ciutat, 2018 .

LEFÈBVRE, Henri. Writing on cities. UK: Blackwell Publishers, 1996.

MENDES, Luís. Gentrificação turística em Lisboa: neoliberalismo, financeirização e urbanismo austeritário em tempos de pós-crise capitalista 2008-2009. São Paulo: Cadernos Metrópole v. 19, n. 39, 479-512, 2017.

PINK, Sarah. Doing visual ethnography. London: Sage Publications, 2013.

QUEIRÓS, João. A disappearing world: the ever-expandier "frontier of gentrification" through the eyes of Porto's historic centre long-time residents. In Gentrification as a Global Strategy: Neil Smith and Beyond, Albert \& Benach (Eds), New York: Routledge, 2017.

SCHAFER, R. Murray. The Soundscape. Destiny Books, 1993.

Recebido: 30/01/2021

Aprovado: 02/06/2021 